\title{
HUBUNGAN KEMAMPUAN AWAL MATEMATIKA DENGAN KEMAMPUAN PEMAHAMAN KONSEP MATEMATIKA SISWA KELAS VIII SMP 12 TARAKAN
}

\author{
Ferryansyah $^{1}$, Azwar Anwar ${ }^{2}$ \\ ${ }^{1,2}$ Pendidikan Matematika, Universitas Borneo Tarakan \\ ${ }^{1}$ Email : vrsyah.math@borneo.ac.id \\ ${ }^{2}$ Email : azwaranwar@borneo.ac.id
}

\begin{abstract}
The purpose of this study was to determine the relationship between the ability of early mathematics with the ability to understand mathematical concepts of eighth grade students of SMP Negeri 12 Tarakan. This type of research uses ex post facto research. The population in this study were all students of class VIII of SMP Negeri 12 Tarakan and research samples of students of class VIII-4 by using simple random sampling. Data collection techniques using instrument the ability of early mathematics test and the ability to understand mathematical concepts test with using Pearson Correlation test data analysis. Based on the analysis results obtained by the correlation coefficient values obtained by 0.674 and the value of $r=1$. So that the relationship between the two variables is a strong relationship with a positive direction. The significance value of $0,000<0.05$ which means rejecting $\mathrm{H}_{0}$ and accepting $\mathrm{H}_{1}$. Thay way there is a relationship between the ability of early mathematics with the ability to understand mathematical concepts of eighth grade students of SMP Negeri 12 Tarakan.
\end{abstract}

Keywords: Ability of Early Mathematics, Ability to Understand Mathematical Concepts

\begin{abstract}
Abstrak
Tujuan penelitian ini adalah untuk mengetahuihubungan kemampuan awal matematika dengan kemampuan pemahaman konsep matematika siswa kelas VIII SMP Negeri 12 Tarakan. Jenis penelitian menggunakan penelitian expost facto.Populasi pada penelitian ini adalah seluruh siswa kelas VIII SMP Negeri 12 Tarakan dan sampel penelitian siswa kelas VIII-4 dengan menggunakan simple random sampling. Teknik pengumpulan data menggunakan instrumen tes kemampuan awal matematika dan tes kemampuan pemahaman konsep matematika dengan menggunakan analisis data uji Korelasi Pearson.Beradasarkan hasil analisis diperoleh nilai nilai koefisien korelasi sebesar 0,674 dan nilai $r=1$. Sehingga hubungan kedua variabel merupakan hubungan kuat dengan arah positif. Adapun nilai signifikansi sebesar $0,000<0,05$ yang berari tolak $\mathrm{H}_{0}$ dan terima $\mathrm{H}_{1}$. Dengan demikian ada hubungan kemampuan awal matematika dengan kemampuan pemahaman konsep matematika siswa kelas VIII SMP Negeri 12 Tarakan.
\end{abstract}

Kata kunci: Kemampuan Awal Matematika, Kemampuan Pemahaman Konsep Matematika

Cara Menulis Sitasi: Ferryansyah., Anwar, A. (2020). Hubungan Kemampuan Awal Matematika Dengan Kemampuan Pemahaman Konsep Matematika Siswa Kelas VII SMP 12 Tarakan. Mathematic Education and Aplication Journal,volume 2 no.1, hal 8-14.

Matematika merupakan bidang ilmu yang bertujuan melatih kemampuan komunikasi peserta didik dalam menggunakan bahasa simbo-simbol, angka-angka, dan membantu mempertajam kemampuan penalaran dalam menyelesaiakan permasalahan dalam kehidupan sehari-hari. Hal ini sejalan menurut James dan James (dalam Suciaty, 2017) bahwa matematika adalah ilmu tentang logika yang menyangkut bentuk, susunan, besaran, dan konsep-konsep. Tersirat dalam fikiran bahwa dalam memahami bentuk, susunan yang terkandung dalam simbol-simbol tersebut, maka hal terpenting pertama yang harus dimiliki adalah pemahaman tentang simbol-simbol tersebut (Hudoyo dalam Lenterak, 2011). Oleh karena itu, keberadaan pembelajaran matematika di sekolah akan sangat 
membantu dalam menanamkan pengetahuan dan membentuk pola pikir siswa dalam belajar matematika.

Pengetahuan yang diperoleh melalui pembelajaran matematika di sekolah tersusun secara hirarki. Sehingga pengetahuan yang diperoleh siswa sekarang akan menjadi bekal untuk mempelajari materi pada tingkat selanjutnya. Hal ini sesuai yang diungkapkan oleh Hanun (2012) bahwa pengetahuan dasar yang dimiliki sebelum belajar matematika akan menjadi syarat awal dalam mempelajari materi baru atau lanjutan disebut sebagai kemampuan awal matematika. Menurut Reigluth (dalam Hamzah B. Uno, 2011) salah satu jenis kemampuan awalyaitu strategi kognitif yang menyediakan cara mengolah pengetahuan baru, mulai dari penyandian, penyimpanan, sampai pada pengungkapan kembali pengetahuan yang telah tersimpan dalam ingatan. Hal ini tentu akan berdampak pada pengembangan kemampuan pemahaman konsep siswa.

Permendiknas No.22 Tahun 2006, Standar Isi Mata Pelajaran Matematika pada tingkat Pendidikan Dasar dan Menengah disebutkan bahwa tujuan pembelajaran matematika di sekolah adalah agar siswa memiliki kemampuan memahami konsep, penalaran, pemecahan masalah, komunikasi dan menghargai kegunaan matematika dalam kehidupan. Terlihat bahwa kemampuan pemahaman konsep merupakan salah satu yang harus dikuasai oleh siswa. Hal ini karena dengan kemampuan pemahaman konsep yang baik peserta didik dapat membekali dirinya dalam memecahkan permasalahan matematika yang ada. Disamping itu, tentu kemampuan pemahaman konsep diperlukan sebagai dasar dalam mencapai pengetahuan matematika pada tingkat yang lebih tinggi. Menurut Hudojo (2007) bahwa kemmapuan pemahaman konsep adalah suatu ide abstrak yang memungkinkan seseorang mengklasifikasikan objek-objek atau peristiwa-peristiwa itu termasuk atau tidak termasuk dalam ide abstrak tersebut. Artinya seseorang paham suatu konsep jika mampu untuk memberikan contoh atau non contoh dari suatu konsep yang dipelajarinya. Lebih lanjut menurut Wardhani (2008) seseorang dikatakan mempunyai kemampuan pemahaman konsep jika dapat 1) menyatakan ulang sebuah konsep, 2) mengklasifikasikan objek-objek menurut sifat-sifat tertentu, 3) memberikan contoh dan non contoh ,4) menyajikan konsep dalam berbagai bentuk matematis, 5) mengembangkan syarat perlu atau syarat cukup suatu konsep, 6) menggunakan, memanfaatkan, dan memilih prosedur atau operasi tertentu, 7) mengaplikasikan konsep atau algoritma pemecahan masalah.

Berdasarkan hasil wawancara dengan guru matematika siswa kelas VIII di SMP Negeri 12 Tarakan diperolah bahwa ketika guru bertanya tentang materi sebelumnya, siswa cenderung lupa bahkan harus membuka kembali bukunya untuk melihat materi sebelumnya, masih ada juga siswa terlihat belum menguasai operasi pada bilangan seperti perkalian, pembagian, penjumlahan, penguruangan yang merupakan pengetahuan dasar dalam belajar matematika. Sehingga siswa merasa kesulitan dalam memahami materi yang akan diberikan saat di kelas. Ketika belajar siswa kurang dapat mengklasifikasikan objek, seperti himpunan dan bukan himpunan. Selain itu, ketika siswa 
diberikan permasalahan dalam kehidupan sehari, terlihat siswa kurang mampu menggunakan konsep yang sudah dipelajari untuk menyelesaikan soal tersebut.Beberapa permasalahan tersebut berkaitan erat dengan kemampuan awal dan kemampuan pemahaman konsep matematika siswa kelas VIII SMP Negeri 12 Tarakan.

Oleh karena itu, berdasarkan pada permasalahan berkaitan dengan kemampuan awal dan kemampuan pemahaman konsep matematika siswa peneliti ingin mengkaji tentang ada tidaknya hubungan kemampuan awal matematika dengan kemampuan pemahaman konsep matematika siswa di SMP Negeri 12 Tarakan.

\section{METODE}

Penelitian ini merupakan penelitianexpost facto dengan pendekatan kuantitatif. Tujuan penelitian ini adalah untuk mengetahui ada tidaknya hubungan kemampuan awal matematika dengan kemampuan pemahaman konsep matematika siswa kelas VIII SMP 12 Tarakan. Penelitian ini berlokasi di SMP Negeri 12 Tarakan, Kalimantan Utara. Populasi pada penelitian ini seluruh siswa kelas VIII SMP Negeri 12 Tarakan pada mata pelajaran matematika. Sampel peneltian hanya mengambil satu kelas, yaitu kelas VIII-4 dengan menggunakan simple random sampling(Sugiyono, 2018). Teknik pengumpulan data menggunakan instrumen tes untuk mengukur kemampauan awal matematika siswa dan kemampuan pemahaman konsep matematika. Data yang diperoleh kemudian dianalisismenggunakan analisis statistik deskriptif dan analisis statisitik inferensial.

Adapun pengkategorian pada analisis statistik deskriptif umtuk kemampuan awal matematika siswa menggunakan tabel di bawah ini.

Tabel 1. Kategori Kemampuan Awal Matematika

\begin{tabular}{|c|c|}
\hline Rata - Rata Skor & Kategori \\
\hline $80-100$ & Sangat baik \\
\hline $68-79$ & Baik \\
\hline $55-67$ & Sedang \\
\hline $45-54$ & Kurang \\
\hline$<45$ & Sangat Kurang \\
\hline
\end{tabular}

Sumber: Ginting (2010)

Sedangkan untuk mengkategorikan kemampuan pemahaman konsep matematika menggunakan tabel di bawah ini. 
Tabel 2. Kategori Kemampuan Pemahaman Konsep

\begin{tabular}{|c|c|}
\hline Skor & Kategori \\
\hline $83,25<\mathrm{X} \leq 100$ & Sangat baik \\
\hline $77<\mathrm{X} \leq 83,25$ & Baik \\
\hline $70,75<\mathrm{X} \leq 77$ & Sedang \\
\hline $64,5<\mathrm{X} \leq 70,75$ & Kurang \\
\hline $0 \leq \mathrm{X} \leq 64,5$ & Sangat Kurang \\
\hline
\end{tabular}

Sumber : Modifikasi Sudijono (2009)

Analisis Statistik inferensial menggunakan uji Korelasi Pearsonatau Korelasi Product Moment (Arikunto, 2012) untuk mencari hubungan kemampuan awal matematika dengan kemampuan pemahaman konsep matematika siswa.

Keterangan:

$$
r_{x y}=\frac{n\left(\sum X Y\right)-\left(\sum X\right) \cdot\left(\sum Y\right)}{\left.\sqrt{\left\{n \cdot \sum X^{2}\right.}-\sum(X)^{2}\right\}\left\{n \cdot \sum Y^{2-\sum(Y)^{2}}\right\}}
$$

$r_{x y}=$ Koefisien korelasi yang menyatakan validasi

$\sum \mathrm{X}=$ Jumlah skor item

$\sum \mathrm{Y}=$ Jumlah skor total (seluruh item)

$\sum \mathrm{X}^{2}=$ Jumlah kuadrat skor item

$\sum \mathrm{Y}^{2}=$ Jumlah kuadrat skor total (seluruh item)

$\mathrm{n}=$ Banyaknya siswa

$\mathrm{X}=$ Skor item

$\mathrm{Y}=$ Skor total (seluruh item)

Untuk memberikan interpretasi pada koefisen korelasi digunakan pedoman interpretasi koefisien korelasi sebagai berikut.

Tabel 3. Kategori Kemampuan Pemahaman Konsep

\begin{tabular}{|c|c|}
\hline Koefisien Korelasi & Tingkat Hubungan \\
\hline $0,000-0199$ & Sangat Rendah \\
\hline $0,200-0,399$ & Rendah \\
\hline $0,400-0,599$ & Sedang \\
\hline $0,600-0,799$ & Kuat \\
\hline $0,800-1,000$ & Sangat Kuat \\
\hline
\end{tabular}

Sumber : Sugiyono (2012)

Sedangkan hipotesis yang digunakan untuk kepeluan menguji hipotesis disajikan sebagai berikut

$\mathrm{H}_{0}: \mathrm{P}=0$ (tidak ada hubungan kemampuan awal matematika dengan kemampuan pemahaman konsep matematika siswa Kelas VIIISMP Negeri 12 Tarakan)

$\mathrm{H}_{1}: \mathrm{P} \neq 0$ (ada hubungan kemampuan awal matematika dengan kemampuan pemahaman konsep matematika siswaKelas VIII SMP Negeri 12 Tarakan) 


\section{HASIL DAN PEMBAHASAN}

Penelitian dilaksanakan di kelas VIII SMP Negeri 12 Tarakan pada mata pelajaran matematika. Penelitian mulai dilaksanakan pada tanggal 15 Oktober 2019 sampai dengan 31 Oktober 2019. Adapun hasil analisis statistik deskriptif pada kemampuan awal matematika siswa diberikan pada tabel di bawah ini.

Tabel 4. Hasil Analisis Deskriptif Kemampuan Awal Matematika Siswa

\begin{tabular}{|c|c|c|c|c|c|}
\hline & N & Minimum & Maximum & Mean & Std. Deviasi \\
\hline Kelas VIII-5 & 32 & 60,75 & 92,75 & 75,75 & 6,75 \\
\hline
\end{tabular}

Terihat pada tabel 4 bahwa rata-rata kemampuan awal matematika siswa Kelas VIII SMP Negeri 12 Tarakan sebesar 75,75 dari jumlah sampel sebanyak 32 orang. Ini berarti bahwa kemampuan awal matematika tergolong baik. Sedangkan hasil analisis statistik deskriptif pada kemampuan pemahaman konsep matematika siswa diberikan pada tabel di bawah ini.

Tabel 5. Hasil Analisis Deskriptif Kemampuan Pemahaman Konsep Matematika Siswa

\begin{tabular}{|c|c|c|c|c|c|}
\hline & N & Minimum & Maximum & Mean & Std. Deviasi \\
\hline Kelas VIII-5 & 32 & 57,50 & 80 & 71,50 & 5,75 \\
\hline
\end{tabular}

Terihat pada tabel 5 bahwa rata-rata kemampuan pemahaman konsep matematika siswa kelas VIII SMP Negeri 12 Tarakan sebesar 71,50 dari jumlah sampel sebanyak 32 orang, dengan memberikan 6 soal tes kemampuan pemahaman konsep matematika. Dengan demikian bahwa hasil kemampuan pemahaman konsep matematika siswa berada pada kategori sedang.

Sebelum melakukan uji inferensial terlebih dahulu dilakukan pengecekan normalitas dan kelinearan data. Berdasarkan uji normalitas menggunakan uji Kolmogorov-Smirnovpada kemampuan awal matematika siswa diperoleh 0,102>0,05 artinya data berdistribusi normal. Sedangkan pada kemampuan pemahaman konsep matematika siswa diperoleh 0,200>0,05 artinya data juga berdistribusi normal.Uji kelinearan pada kemampuan awal matematika terhadap kemampuan pemahaman konsep matematika siswa diperoleh nilai siginfikansi linearitasnya sebesar 0,069>0,05. Dengan demikian terdapat hubungan linear antara kemampuan awal matematika dan kemampuan pemahaman konsep matematika siswa. 
Sementara untuk menjawab ada tidaknya hubungan antara kemampuan awal matematika dengan kemampuan pemahaman konsep matematika siswa, selanjutnya digunakan uji Korelasi Pearson. Adapun hasilnya dapat dilihat pada tabel berikut.

Tabel 6. Uji Korelasi Kemampuan Awal Matematika dengan Memampuan Pemahaman Konsep Matematika Siswa

\begin{tabular}{|l|l|r|r|}
\hline \multicolumn{2}{|c|}{} & \multicolumn{1}{|c|}{ KPKM } & \multicolumn{1}{|c|}{ KAM } \\
\hline KPKM & Pearson Correlation & 1 & $.674^{* *}$ \\
\cline { 2 - 4 } & Sig. (2-tailed) & & .000 \\
\cline { 2 - 4 } & N & 32 & 32 \\
\hline \multirow{3}{*}{ KAM } & Pearson Correlation & $.674^{* *}$ & 1 \\
\cline { 2 - 4 } & Sig. (2-tailed) & .000 & \\
\cline { 2 - 4 } & N & 32 & 32 \\
\hline
\end{tabular}

**. Correlation is significant at the 0.01 level (2-tailed).

Berdasarkan tabel 3.3koefisien korelasi sebesar 0,674 dan nilai $r=1$. Hal ini menunjukkan hubungan pada kategori kuat dan dengan arah positif. Kemudian untuk menguji hipotesis untuk pengambilan keputusan diperoleh nilai signifikansi sebesar $0,000<0,05$ yang berari tolak $\mathrm{H}_{0}$ dan terima $\mathrm{H}_{1}$. Dengan demikian ada hubungan kemampuan awal matematika dengan kemampuan pemahaman konsep matematika siswakelas VIIISMP Negeri 12 Tarakan. Oleh karena itu dapat disimpulkan jika ada sebagian siswa yang mempunyai kemampuan awal baik, maka akan memiliki kemampuan pemahaman konsep yang sedang. Begitu pula juga sebaliknya. Tetapi ada juga siswa yang mempunyai kemampuan awal baik, akan memiliki kemampuan pemahaman konsep yang baik pula.

\section{KESIMPULAN}

Berdasarkan hasil tersebut dapat disimpulkan bahwa kemampuan awal matematika siswa kelas VIII SMP Negeri 12 Tarakan berada pada kategori baik dengan rata-rata Kemampuan awal matematika sebesar 75,75. Kemampuan pemahaman konsep matematika siswa kelas VIII SMP Negeri 12 Tarakan berada pada kategori sedang dengan rata-rata pemahaman konsep matematika sebesar 71,50. Terdapat hubungan yang kuat antara kemampuan awal matematika dengan kemampuan pemahaman konsep matematika siswa kelas VIII SMP Negeri 12 Tarakan. 


\section{DAFTAR PUSTAKA}

Arikunto, Suharsimi. (2012). Dasar-Dasar Evaluasi Pendidikan Edisi 2. Jakarta: PT. Bumi Aksara.

Hamzah B. Uno. (2011). Perencanaan pembelajaran. Jakarta: PT. Bumi Aksara.

Hanun, F. (2012). Pengaruh Metode Pembelajaran terhadap dan Kemampuan Awal Matematika terhadap Hasil Belajar". JurnalStudy Eksprimen.

Hudojo, Herman. (2001). Pengembangan Kurikulum dan Pengembangan Matematika. Malang: UNM Malang. Departemen Pendidikan Nasional.

Lenterak. (2011). Pembelajaran Matematika di Sekolah, (online), (https://lenterakecil.com/pembelajaran-matematika-di-sekolah/), diakses 12 April 2020.

Permendiknas. (2006). Standar Isi Mata Pelajaran Matematika Untuk Semua Jenjang Pendidikan Dasar Dan Menengah. Menteri Pendidikan Nasional. Jakarta.

Suciaty, Andi Hikmah. 2017. Pengaruh Model Pembelajaran Kooperatif Tipe Thinking Aloud Pair Problem Solving (TAPPS) Terhadap Kemampuan Pemecahan Masalah Matematika Ditinjau Dari Disposisi Matematis Siswa Kelas VIII SMP Negeri 5Tarakan. Universitas Boreno Tarakan, Skripsi: Tidak Dipublikasikan.

Sudijono, Anas. 2009. Pengantar Evaluasi Pendidikan. Jakarta: Rajawali Pers.

Sugiyono, 2012, Metode Penelitian Pendidikan, Alfabeta, Bandung.

Sugiyono. 2018. Metode Penelitian Kuantitatif, Kualitatif, dan R \& D. Bandung: Alfabeta.

Wardhani, Sri. 2008. Analisis SI dan SKL Mata Pelajaran Matmatika SMP/Mts untuk Optimalisasi Tujuan Pelajaran Matematika: Paket Fasilitas Pemberdayaan KKG/MGMP Matematika. Yogyakarta: Pusat Pengembangan dan Pemberdayaan Pendidik dan Tenaga Kependidikan Matematika. 